\title{
Article
}

\section{Does self-monitoring reduce blood pressure? Meta-analysis with meta- regression of randomized controlled trials}

Bray, Emma, Holder, R, Mant, J and McManus, R J

Available at http://clok.uclan.ac.uk/7451/

Bray, Emma ORCID: 0000-0001-9882-3539, Holder, R, Mant, J and MCManus, $R$ $J$ (2010) Does self-monitoring reduce blood pressure? Meta-analysis with meta-regression of randomized controlled trials. Annals of Medicine, 42 (5). pp. 371-386. ISSN 0785-3890

It is advisable to refer to the publisher's version if you intend to cite from the work. http://dx.doi.org/10.3109/07853890.2010.489567

For more information about UCLan's research in this area go to http://www.uclan.ac.uk/researchgroups/ and search for <name of research Group>.

For information about Research generally at UCLan please go to http://www.uclan.ac.uk/research/

All outputs in CLoK are protected by Intellectual Property Rights law, including Copyright law. Copyright, IPR and Moral Rights for the works on this site are retained by the individual authors and/or other copyright owners. Terms and conditions for use of this material are defined in the policies page. 


\section{Does self monitoring reduce blood pressure? Meta-analysis with meta regression of randomised controlled trials.}

SANN-2009-0075.R2 Accepted by Annals of Medicine $14^{\text {th }}$ April 2010

Dr Emma P Bray, ${ }^{1} \quad$ Research Fellow

Dr Roger Holder, ${ }^{1} \quad$ Head of Statistics

Prof Jonathan Mant, ${ }^{2} \quad$ Professor of Primary Care Research

Prof Richard J McManus, ${ }^{1}$ Professor of Primary Care Cardiovascular Research

1 Primary Care Clinical Sciences, University of Birmingham, Edgbaston, Birmingham B15 2TT.

2 General Practice \& Primary Care Research Unit, Forvie Site, University of Cambridge, Robinson Way, Cambridge CB2 0SR

Correspondence to Prof Richard J McManus: r.j.mcmanus@bham.ac.uk

Word Count: 2859 


\section{Abstract short version}

Introduction: Self monitoring of blood pressure (BP) is an increasingly common part of hypertension management. The objectives of this systematic review were to evaluate the systolic and diastolic BP reduction, and achievement of target BP, associated with self monitoring.

Methods: Medline and six other databases were searched for studies where the intervention included self monitoring of BP and the outcome was change in office/ambulatory BP or proportion with controlled BP. Two reviewers independently extracted data. Meta analysis using a random effects model was combined with metaregression to investigate heterogeneity in effect sizes.

Results: 25 eligible RCTs were identified. Office systolic (20 RCT’s, 5898 patients) and diastolic BP (23 RCTs, 6038 patients) were significantly reduced in those who self-monitored compared to usual care (weighted mean difference systolic: 3.82mmHg (95 \% CI -5.61, -2.03)/diastolic -1.45 mmHg (-1.95, -0.94)). Self monitoring increased the chance of meeting office BP targets (12 RCTs, 2260 patients; RR = $1.09(1.02,1.16))$. There was significant heterogeneity between studies for all three comparisons which could be partially accounted for by the use of additional co-interventions.

Conclusion: Self-monitoring reduces blood pressure by a small but significant amount. Meta-regression could only account for part of the observed heterogeneity. 


\section{Abstract long version}

Introduction: Self monitoring of blood pressure (BP) is an increasingly common part of hypertension management. The objectives of this systematic review were to evaluate the systolic and diastolic BP reduction, and achievement of target BP, associated with self monitoring.

Methods: MEDLINE, Embase, Cochrane database of systematic reviews, database of abstracts of clinical effectiveness, the health technology assessment database, the NHS economic evaluation database, and the TRIP database were searched for studies where the intervention included self monitoring of BP and the outcome was change in office/ambulatory BP or proportion with controlled BP. Two reviewers independently extracted data. Meta analysis using a random effects model was combined with metaregression to investigate heterogeneity in effect sizes.

Results: 25 eligible RCTs (27 comparisons) were identified. Office systolic (20 RCT’s, 21 comparisons, 5898 patients) and diastolic BP (23 RCTs, 25 comparisons, 6038 patients) were significantly reduced in those who self-monitored compared to usual care (weighted mean difference (WMD) systolic -3.82mmHg (95 \% confidence interval -5.61, -2.03)/diastolic $-1.45 \mathrm{mmHg}(-1.95,-0.94))$. Self monitoring increased the chance of meeting office BP targets (12 RCTs, 13 comparison, 2260 patients, RR $=1.09(1.02,1.16))$. There was significant heterogeneity between studies for all three comparisons which could be partially accounted for by the use of additional cointerventions.

Conclusion: Self-monitoring reduces blood pressure by a small but significant amount. Meta-regression could only account for part of the observed heterogeneity. 
Keywords: Blood Pressure Monitoring, Hypertension, Meta-analysis, SelfMonitoring

\section{Key messages:}

1) Self-monitoring of blood pressure results in small reductions in office blood pressure but there is significant heterogeneity of results between studies

2) Metaregression to investigate this heterogeneity found that additional cointerventions such as telemonitoring or education explained part but not all of the heterogeneity in studies with achievement of blood pressure target as their outcome.

3) Other factors not studied may play an important role in the remaining heterogeneity and may be best studied by an individual patient meta-analysis.

\section{Abbreviations}

mmHg; Millimetres of Mercury

BP; Blood Pressure

RCT(s); Randomised Controlled Trial(s)

SBP: systolic Blood Pressure

DBP: Diastolic Blood Pressure

WMD; Weighted Mean Difference

ABPM: Ambulatory Blood Pressure Measurement

RR: Relative Risk 


\section{Introduction}

Hypertension is a key risk factor for cardiovascular disease, the leading cause of death worldwide. ${ }^{1}$ Therapeutic reduction of blood pressure leads to significant reduction in both stroke and coronary heart disease risk and is cost effective, especially for individuals at higher risk of cardiovascular events. ${ }^{2,3}$ However, international community based surveys indicate that only a minority of people treated for hypertension are controlled to recommended treatment levels. ${ }^{4}$

Self monitoring of hypertension has been proposed as a method for reducing blood pressure over and above standard care by increasing the involvement of individuals in their own treatment and therefore aiming to increase adherence, reduce clinical inertia and provide patients and professionals with common information about the efficacy of treatment. ${ }^{5,6}$ Self measurement is a better predictor of end organ damage than office measurement ${ }^{7}$ and is well tolerated by patients. ${ }^{8,9}$

Previous systematic reviews have found self monitoring of blood pressure to be associated with lower office systolic blood pressure (around $4 \mathrm{mmHg}$ ) as compared to conventional care but also found large variation in effect size with significant heterogeneity between studies. ${ }^{5,10}$ No reviews have reported the effect of self monitoring using ambulatory blood pressure as the outcome. The heterogeneity previously reported may reflect the substantial variation in a number of key variables such as the study setting, the methodologies employed (e.g., length of follow-up, measurement of BP (how, when and by whom), co-interventions, the BP definitions utilised), and the classification criteria for home, self, and usual care. Since these previous meta-analyses were performed, a number of new trials have been published. 
The aim of this study was therefore to provide an updated systematic review of the evidence for self monitoring in hypertension and to explore any heterogeneity found using meta regression. The objectives were to determine the effect of self monitoring of blood pressure in adults on blood pressure and blood pressure control, compared to usual care (no self monitoring of BP). The outcomes used were office and ambulatory systolic and diastolic blood pressure, and number of patients meeting office target blood pressure. [The protocol for this review can be found in appendix 1 (include as web appendix)].

\section{Methods}

Searching

Electronic databases (Medline, Embase, Cochrane database of systematic reviews, database of abstracts of clinical effectiveness, the health technology assessment database, the NHS economic evaluation database, and the TRIP database) were searched in February 2009 for articles published up to and including January 2009, using a search strategy (Appendix 2) based on those used in previous meta-analyses which was designed to capture all randomised controlled trials (RCTs) concerning self monitoring and self management of hypertension. ${ }^{5,10}$ Additionally, reference lists from included studies and previous meta-analyses were searched. Reference titles and abstracts of publications resulting from the search were scrutinised independently by two reviewers and potentially eligible studies reviewed in detail to assess eligibility.

\section{Selection}

RCTs were eligible if the intervention tested included self measurement of BP without medical professional input, if usual care did not include patient self-monitoring, and if 
a blood pressure outcome measure was available that had been taken independently of the self measurement (either systolic or diastolic office pressure or ambulatory monitoring (mean day time ambulatory pressure)). Non randomised designs were excluded. No additional quality criteria in terms of methodology or study size were applied. $^{11}$

\section{Data extraction}

Data were extracted independently using a coding form [included as web appendix 3] by two reviewers (RM and EB) concerning patient characteristics (gender, age), study characteristics (length of follow up), type of self monitoring (home, community), cointerventions (any procedure over and above self monitoring that was included in the intervention including patient education, nurse led support, telemonitoring), and outcomes (see below). Where data were missing from published reports, for instance standard deviations of change, authors were contacted to request such information. Where studies reported more than one outcome time (e.g. 6 and 12 months), data concerning the longest follow up was extracted. In cases of disagreement that could not be resolved by consensus, a third reviewer (JM) adjudicated.

\section{Outcomes}

The outcomes assessed were change in mean office SBP and DBP, change in mean day-time ambulatory SBP and DBP between baseline and follow up for both intervention and control arms, and change in proportion of people with office measured BP controlled below target between intervention and control arms. Data were also collected on whether adjustments were made for self-monitored readings compared to office readings. 


\section{Quantitative data synthesis}

Analyses were performed with STATA 10.1 (Statacorp) using a random-effects model (metan command). Weighted mean differences (WMD) were calculated for the overall mean change in systolic and diastolic blood pressure (both office and ABPM) between intervention and control, with relative risk (RR) used when percentage of patients with BP above target at final follow-up was reported. The weighting depended on the standard deviation of the change in BP from baseline to final reading and this value was not always reported but standard deviations at baseline and final measurements were given. Elementary theory of differences of correlated variables was used to estimate the standard deviation of change on those occasions. The correlation between baseline and final result was estimated from studies where all three standard deviations were reported and then used in conjunction with the latter two standard deviations to estimate the standard deviation of change when not available. Where either of the latter two standard deviations were missing then an average value from the other studies was imputed. [The data used and an explanation of the standard deviation estimation can be found in web appendix 4].

Clinical heterogeneity was assessed using a chi-square test for systematic variation and $\mathrm{I}^{2}$. Heterogeneity was further explored using meta-regression with backward elimination to analyse the associations between treatment effect and the study characteristics (metareg command). Where a significant moderator of the heterogeneity was found, studies were grouped using this moderator and if heterogeneity of effect size persisted with respect to blood pressure change, further meta regression was performed within groups. A priori, on the basis of results from 
previous studies suggesting an effect on outcome, we included terms for age (continuous) and sex of participants, ${ }^{12,13}$ length of follow up (continuous), ${ }^{6}$ use of additional co-interventions (where these were part of the intervention in addition to self monitoring), ${ }^{10}$ adjustment made for self-monitored BP readings, and inclusion criteria for diastolic blood pressure (DBP of $\geq 90 \mathrm{v} \geq 95 \mathrm{mmHg}$ ) in the regression models. ${ }^{5}$ Meta-regression was not used for the ambulatory BP outcome, due to the small number of studies involved. A series of sensitivity analyses were performed to assess the impact of each study on the overall outcome with recalculation of both the weighted mean differences and meta regression as each study was removed one at a time from the analysis. A specific sensitivity analysis considered whether studies with multiple arms influenced the degree of heterogeneity as measured by $\mathrm{I}^{2}$.

Publication bias was assessed by producing funnel plots of effect size and of sample size against WMD to provide a visual review of any potential bias.

\section{Results}

The search results are presented in Figure 1. Of 630 studies included in the original search results, 25 studies including 27 comparisons were eligible for the meta analysis

(Table 1). Two studies included three arms and so were included twice. ${ }^{14,15}$ Of these, 20 RCTs (21 comparisons, 5898 patients) contained extractable data on change in office systolic blood pressure, 23 RCTs (25 comparisons, 6038 patients) data for change in office diastolic blood pressure, 12 RCTs, (13 comparisons, 2260 patients) data for achievement of office blood pressure target and three studies for change in mean day time ambulatory BP (SBP and DBP) (3 comparisons, 572 patients). 
Nine studies included follow up of one year or more and the mean age of participants ranged from 47 to 77 with 18 studies having a mean age of less than 60 (table 1). Six studies included 200 or more patients per randomised group. Thirteen studies included no additional intervention other than self monitoring. Additional co-interventions over and above self monitoring included patient education (7 studies), phone contact or home visits (7 studies), family involvement (1 study) and telemetry (6 studies). Seven studies included more than one additional co-intervention. The treating physician was aware of self blood pressure readings in 16 studies.

\section{Office Systolic Blood Pressure}

Systolic blood pressure was significantly reduced in those who received selfmonitoring compared to usual care (weighted mean difference $=-3.82 \mathrm{mmHg}$, $(95 \%$ CI -5.61 to -2.03) Figure 2). However, there was a high level of heterogeneity between the studies $\left(\mathrm{I}^{2}=71.9 \%, \mathrm{p}<.001\right)$. Subsequent meta-regression demonstrated that of the six variables investigated as moderators for this heterogeneity, none approached significance (Table 2).

Sensitivity analyses, which examined the influence of each individual study on the overall effect size estimate by removing each study in turn from the analysis, revealed a range of weighted mean differences of between -3.14 and $-4.11 \mathrm{mmHg}$, with no single study affecting the overall heterogeneity. In particular the Green study which was included twice did not have any distorting effect.

\section{Office Diastolic Blood pressure}


Diastolic blood pressure was significantly reduced in those who received selfmonitoring compared to usual care (weighted mean difference $=-1.45 \mathrm{mmHg}$ (95 \% CI -1.95 to -0.94), Figure 3). Again, there was significant (albeit this time moderate) heterogeneity between the studies $\left(\mathrm{I}^{2}=42.1 \%, \mathrm{p}<0.01\right)$. Meta-regression demonstrated that none of the six variables investigated as moderators approached significance (Table 2).

The range of weighted mean differences seen in the sensitivity analysis removing each study in turn from the analysis was between -1.23 and $-1.62 \mathrm{mmHg}$. On five occasions, removing a single included study had an effect on the resultant metaanalyses and meta-regressions of the remaining studies: with Haynes ${ }^{16}$ removed gender approached significance as a moderator $(\mathrm{p}=0.075)$ and with Binstock, ${ }^{17}$ Green (a), ${ }^{14}$ Parati $^{18}$ and Marquez-Contreras ${ }^{19}$ removed, co-interventions approached significance as a moderator ( $\mathrm{p}=0.056, \mathrm{p}=0.069, \mathrm{p}=0.05, \mathrm{p}=0.091$, respectively). A sensitivity analysis of the two trials included twice examining their effect on z scores and $\mathrm{I}^{2}$ was consistent with the magnitude of the individual effect sizes and suggested no distortion caused by including both arms of these trials.

\section{Office Target Blood Pressure}

Self monitoring of blood pressure (12 RCTs, 13 comparisons) increased the chance of meeting target compared to usual care (relative risk $=1.09$ (95\% CI 1.02 to 1.16$)$, Figure 4). There was significant heterogeneity between the studies $\left(\mathrm{I}^{2}=73.6 \%\right.$, $\mathrm{p}$ $<.01)$ which was moderated by the presence of a co-intervention $(t=2.39, \mathrm{p}<0.05)$ in the meta-regression (Table 2). Where self monitoring was accompanied by an additional co-intervention, participants were more likely to meet target BP compared 
to where there was none $(\mathrm{RR}=1.34,(95 \% \mathrm{CI} 1.2$ to 1.51$)$, vs $\mathrm{RR}=0.98,(95 \% \mathrm{CI}$ 0.91 to 1.05$)$ ). However, none of the other included moderators could explain the heterogeneity which remained in both groups.

Sensitivity analyses showed that removing each study individually made little difference to the overall relative risk (range 0.97 to 1.03 ). None of these analyses affected the remaining heterogeneity in the relative risk.

Fewer than half of the studies reported achievement of target blood pressure as an outcome. To determine if there was bias related to choice of outcome, the SBP and DBP office analyses were re-run including only those studies that also reported target BP. These analyses had little impact on the overall effect size (SBP WMD = 3.2mmHg (95\% CI -5.65 to -0.75), DBP WMD $=-1.45 m m H g(95 \%$ CI -2.57 to 0.47)) suggesting little if any bias in terms of chosen outcome for the target analysis.

\section{Day-time Ambulatory Blood Pressure}

Mean day-time ambulatory blood pressure was reduced but not significantly in those who received self-monitoring compared to usual care (three studies, weighted mean difference $=$ SBP: $-2.04 \mathrm{mmHg}(95 \%$ CI -4.35 to 0.27$), \mathrm{I}^{2}<0.05 \%, \mathrm{p}=0.89$ figure $5 \mathrm{a}$, and DBP: $-0.79 \mathrm{mmHg}$ (95\% CI -2.35 to .77$), \mathrm{I}^{2}<0.05 \% \mathrm{p}=0.96$ ), figure $5 \mathrm{~b}$ ). The $\mathrm{I}^{2}$ suggested homogeneity but has limited power with only three studies. Sensitivity analyses removing each study in turn showed that the Parati study (which included telemonitoring) ${ }^{18}$ had the greatest effect altering the WMD by about $0.5 \mathrm{mmHg}$ in both the SBP and DBP analyses. However, none of these analyses altered the non- 
significant nature of the results. An analysis for target ambulatory BP was not undertaken as these data were only reported in the Parati study.

\section{Publication Bias}

Funnel plots [see web appendix 5] imply several unpublished negative studies may exist but that these are likely to have small $(<100)$ sample sizes and thus little effect on the overall results.

\section{Discussion}

This review has found that self monitoring has a small but significant effect on blood pressure control: As with previous meta-analyses, significant heterogeneity was apparent between all studies with office blood pressure as the outcome. ${ }^{5,10}$ Metaregression to investigate this heterogeneity was not explanatory for the comparisons with office blood pressure as an outcome but sensitivity analyses considering office diastolic pressure showed that five studies individually influenced this heterogeneity. In four cases absence of these studies resulted in co-interventions becoming a significant moderator of this heterogeneity. In the case of the target blood pressure analysis, meta-regression showed that studies including additional co-interventions were more likely to result in blood pressure control and that this explained some but not all of the heterogeneity. Where ambulatory blood pressure was the end point, a smaller and non significant reduction in daytime ambulatory blood pressure was observed. This may reflect a lack of power with only three studies included.

This meta-analysis, unlike previous work, provides some explanation of the heterogeneity observed between studies, particularly in terms of the co-interventions 
used. $^{5,10}$ The range of co-interventions utilised in the included trials was wide and included patient education, health professional support (phone calls, pharmacist involvement, additional clinic visits or home visits), patient led drug titration, techniques designed to increase medication compliance, and use of a website and telemonitoring with automated feedback. It is perhaps unsurprising that these could enhance the effect of self monitoring given that multi faceted interventions are more likely to result in improvements in outcome, and this was seen definitively in the target blood pressure analysis. ${ }^{20}$

Blood pressure drops with repeated measurement, ${ }^{21}$ and it has been previously suggested that habituation to measurement might be the mode of action of self monitoring. The smaller effect size seen in the ambulatory monitoring analysis provides some support for this argument, but included only three studies hence should be interpreted with caution. ${ }^{18,22,23}$ Furthermore, if habituation had a large effect it might have been expected that the length of study would have moderated some of the heterogeneity in the meta regression, but this was not observed.

The recent scientific statement from the American Heart Association, American Society for Hypertension and Preventive Cardiovascular Nurses Association recommends that the target self blood pressure goal for treatment is $<135 / 85 \mathrm{mmHg}$ or $<130 / 80 \mathrm{mmHg}$ in high-risk patients. ${ }^{24}$ The evidence underlying these recommendations is not robust: the majority of trials included in this meta-analyses report target “office blood pressure” of 140/85-95 mmHg but many do not explicitly state whether the same target levels were applied to the self monitoring. The importance of this can be seen from the results from the THOP trial where the same 
target was used for both self and office measurements and it was found that basing treatment decisions on self readings led to higher blood pressures than basing them on office readings. $^{25}$

The current paper includes more than double the number of patients in previous metaanalyses and has resulted in a reduction in the point estimates of effect size for both systolic and diastolic blood pressure. The relatively small effect of self monitoring is likely to result in a lack of power in most included studies (only one of which had enough patients to detect a 3mmHg difference between groups). This fact, along with the evidence from the funnel plots, increases the possibility of unpublished negative studies such as has been postulated previously. ${ }^{5}$

Despite a range of potential moderators chosen a priori to explore the heterogeneity between studies including age, sex, length of follow up, and inclusion diastolic blood pressure, observed heterogeneity remained largely unexplained by this analysis which suggests that other factors may play a role. Possibilities which might be further investigated include: the timing of self monitored readings (variation of blood pressure during the day may impact on patient's perceptions of their BP), the setting of self monitoring (home, at a GP surgery or in the community), and changes in treatment during the study. Further work should also explore the types of cointerventions and how differing combinations of these might optimise the impact on reducing BP and helping patients reach target levels. This might best be done in an individual patient data meta analysis. 


\section{Conclusion}

Self monitoring of blood pressure has a small but significant effect on reduction of office blood pressure when compared to usual care. Co-interventions explain part of the observed heterogeneity between studies which used achievement of target blood pressure as an outcome but most remains unaccounted for. Future investigators should consider carefully the design of their intervention and the use of outcomes such as ambulatory monitoring that are less likely to be affected by habituation to blood pressure measurement. 


\section{Contributorship}

EB, RM and JM performed the searches and extracted the data. EB, RM and RH performed the analyses. All authors participated in the writing of the final document and approved the final version. RM will act as guarantor for the study.

\section{Funding}

This work was funded by an National Institute of Health Research (NIHR) Programme grant. The views expressed in this report are those of the authors and not necessarily those of the NIHR. RM is funded by an NIHR Career Development Fellowship. Birmingham and Cambridge were founder members of the National School for Primary Care Research.

\section{Competing interests}

The authors declare that they have no competing interests regarding this paper

\section{Acknowledgements}

We would like to thank the following authors and their teams for sending us requested data to aid with the analyses: BM Mehos, A Baque, AJ Zillich. 


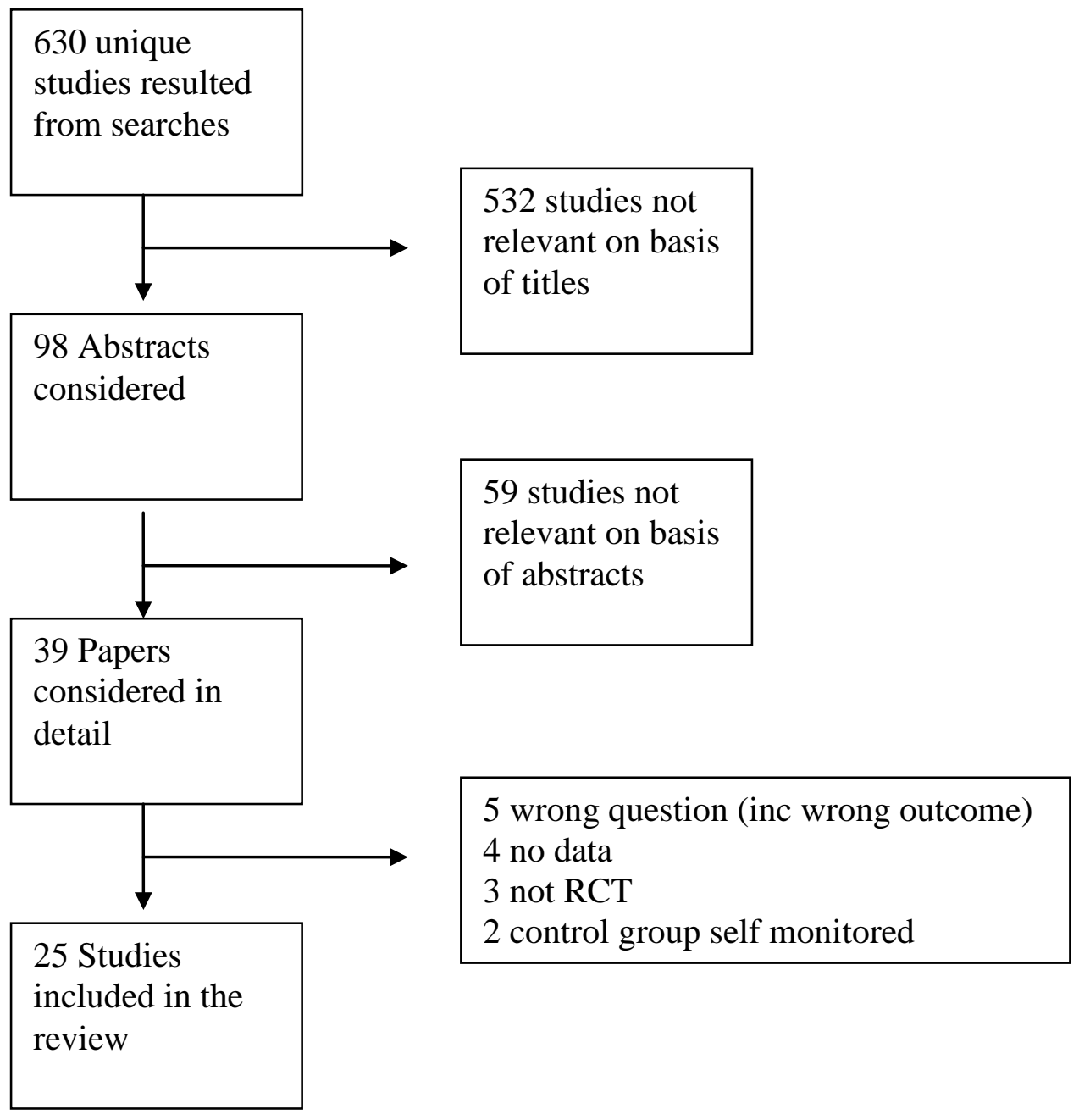

Figure 1 Flow chart of search results 
Figure 2: Overall Office Systolic BP results

Study

ID
$\%$

WMD $(95 \% \mathrm{Cl}) \quad$ Weight

$-18.00(-27.13,-8.87) \quad 2.61$

$-2.60(-7.26,2.06) \quad 5.22$

$-3.30(-6.77,0.17) \quad 6.19$

$-5.00(-10.45,0.45) \quad 4.62$

$-0.90(-4.98,3.18) \quad 5.68$

$5.00(-6.07,16.07) \quad 1.98$

$-0.50(-3.07,2.07) \quad 6.91$

$-10.10(-20.61,0.41) \quad 2.14$

$-25.60(-41.78,-9.42) \quad 1.07$

$-2.00(-16.33,12.33) \quad 1.31$

$-8.50(-14.16,-2.84) \quad 4.47$

$-0.14(-2.05,1.77) \quad 7.37$

$-3.10(-7.93,1.73) \quad 5.08$

$-2.30(-5.47,0.87) \quad 6.44$

$-4.40(-10.52,1.72) \quad 4.16$

$-4.60(-9.01,-0.19) \quad 5.42$

$0.50(-3.65,4.65) \quad 5.63$

$-3.40(-5.91,-0.89) \quad 6.95$

$-9.30(-11.80,-6.80) \quad 6.96$

$-0.20(-3.84,3.44) \quad 6.04$

$-3.82(-5.61,-2.03) \quad 100.00$

Parati (2009)

Overall $(\mathrm{I}$-squared $=71.9 \%, \mathrm{p}=0.000)$

NOTE: Weights are from random effects analysis

\begin{tabular}{ccccccc|c|c|c|c|}
\hline & $\mid$ & $\mid$ & $\mid$ & $\mid$ & & $\mid$ & $\mid$ & $\mid$ & $\mid$ & $\mid$ \\
-50 & -40 & -30 & -20 & -10 & 0 & 10 & 20 & 30 & 40 & 50
\end{tabular}

Favours Intervention

Favours Control 


\section{Figure 3:Overall Office Diastolic BP results}

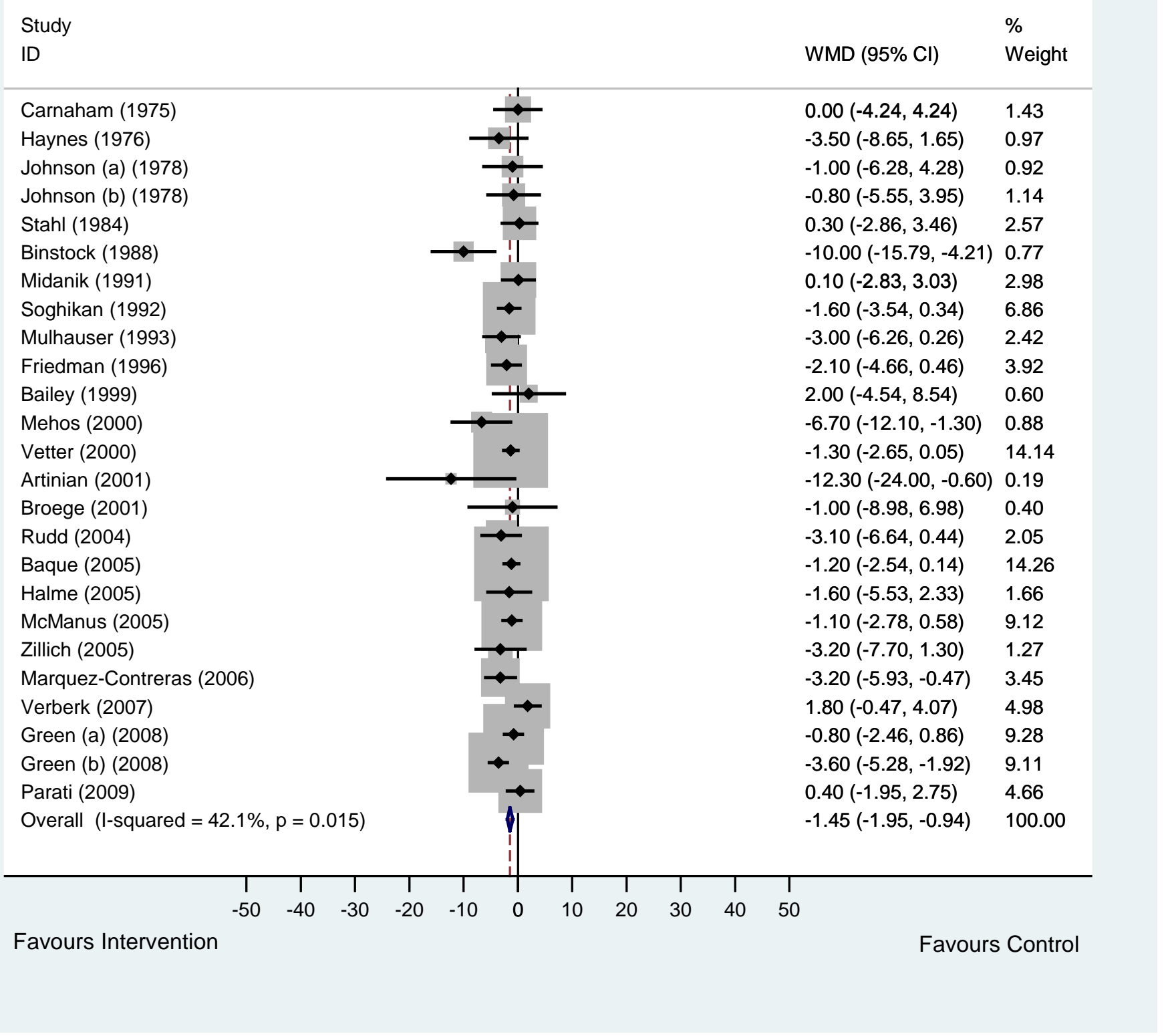


Figure 4: Office Target BP results

Study

ID

RR (95\% Cl)

Weight

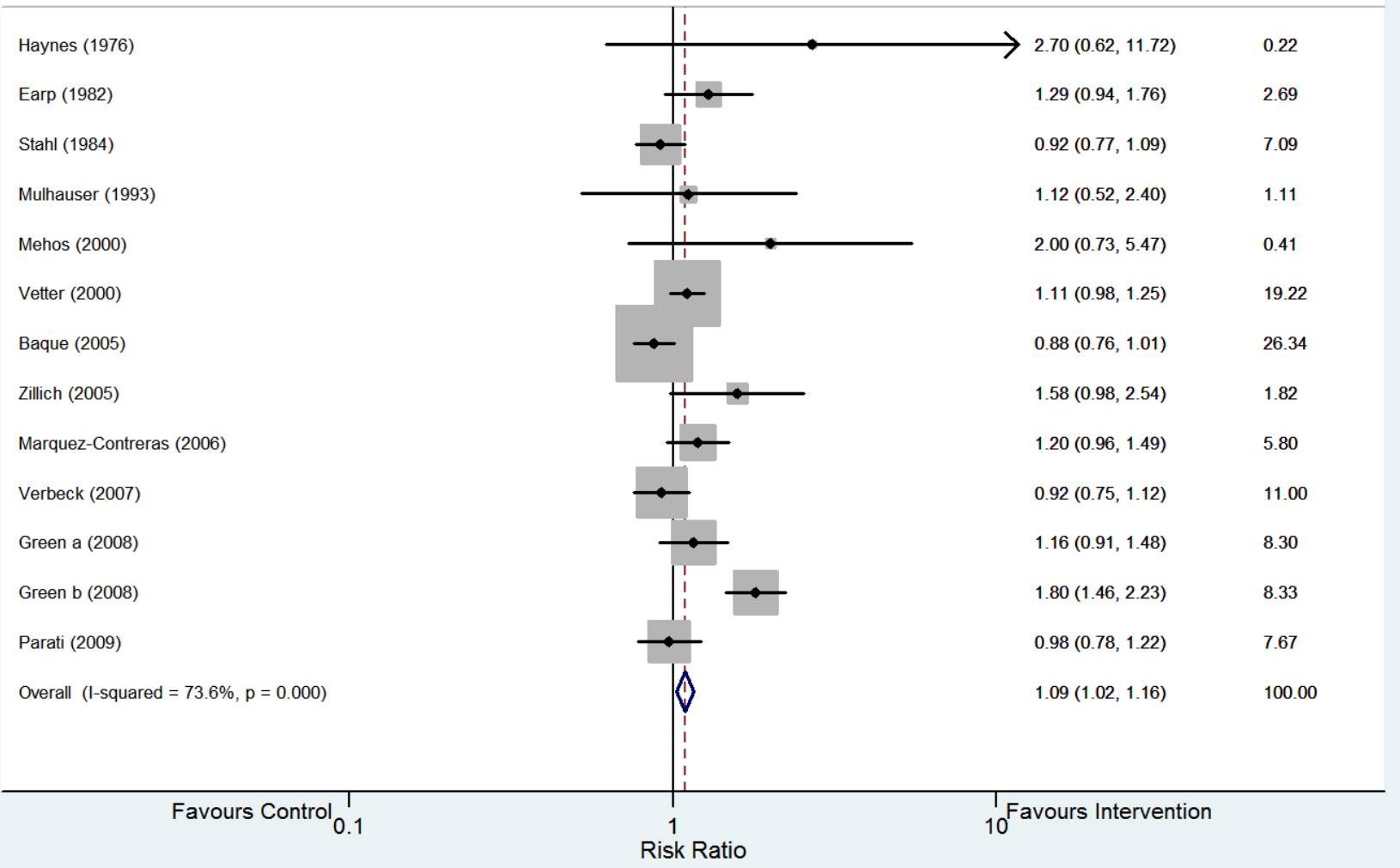


Figure 5a: Daytime Ambulatory SBP results

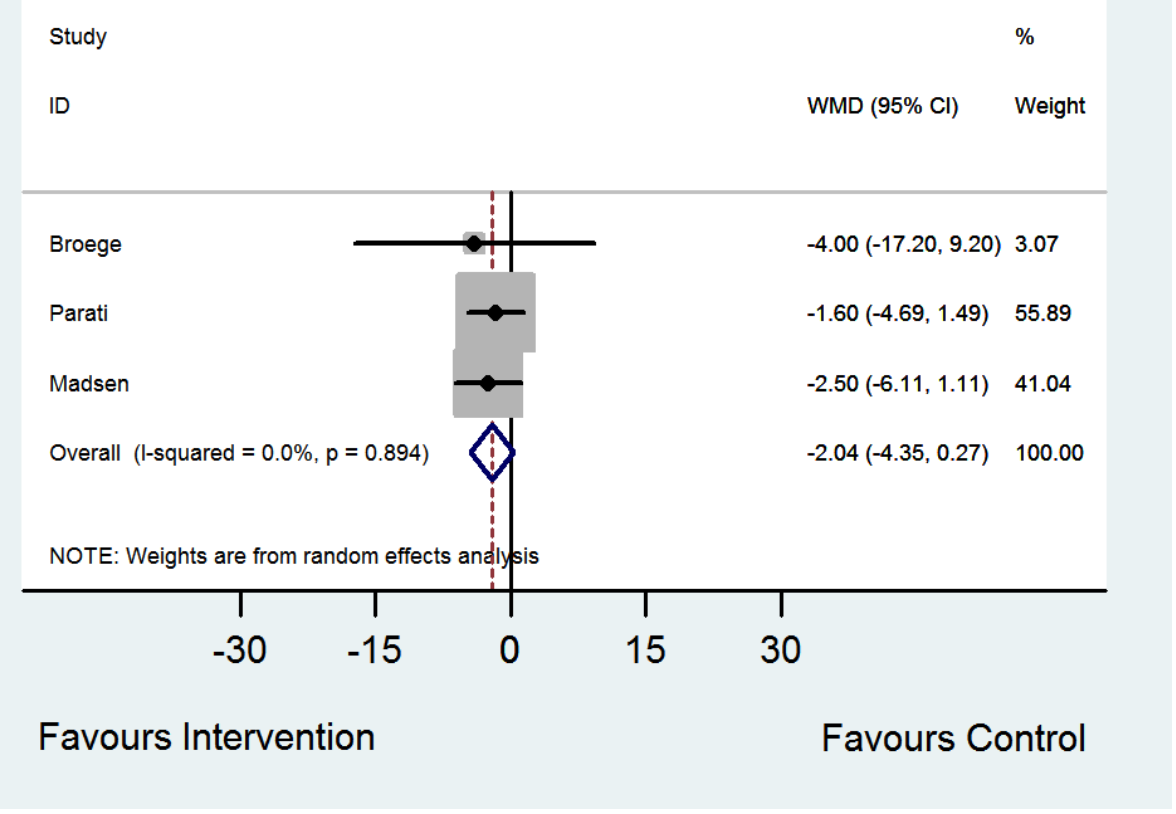

Figure 5b: Daytime Ambulatory DBP results

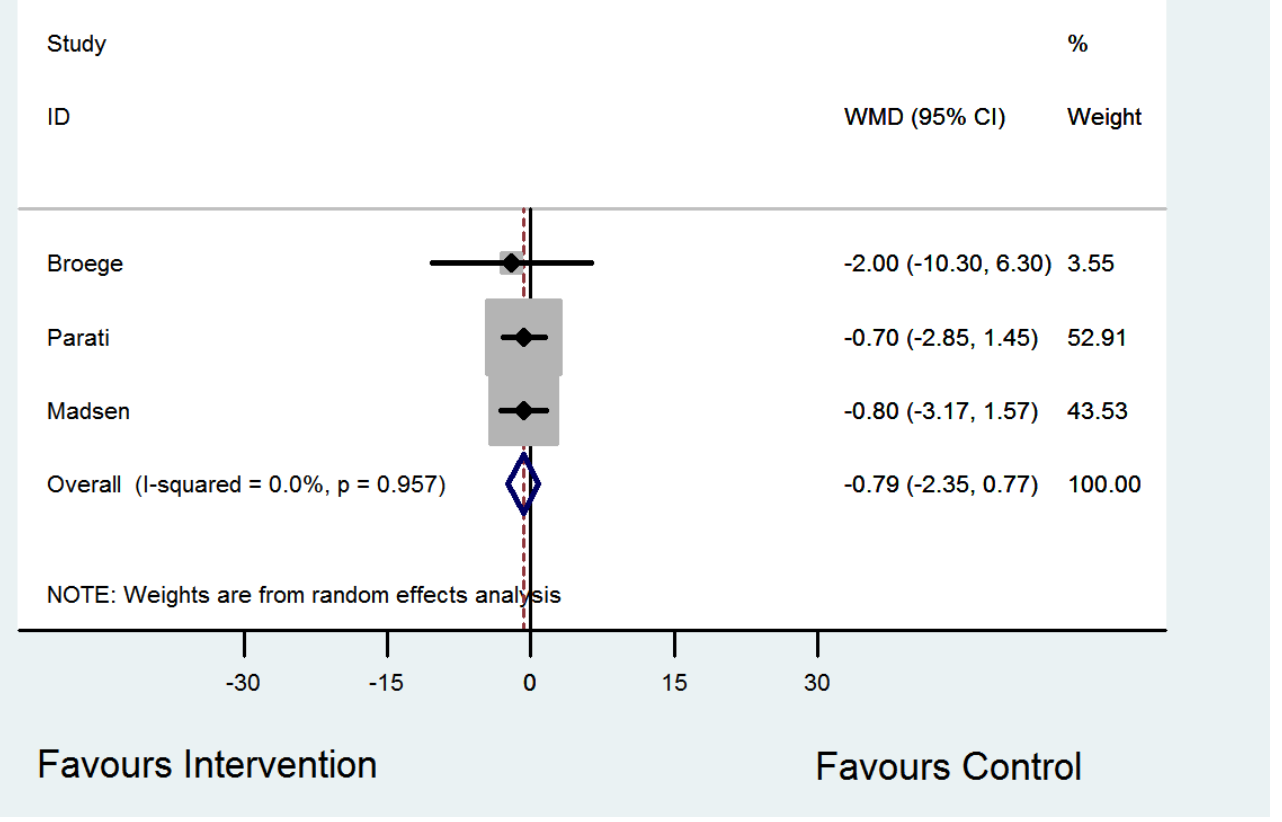


Table 1 Summary of randomised studies of self monitoring of blood pressure

\begin{tabular}{|c|c|c|c|c|c|c|c|c|c|c|}
\hline Study & $\begin{array}{l}\text { Setting and } \\
\text { subjects }\end{array}$ & $\begin{array}{l}\text { Mean } \\
\text { Age } \\
\text { (years) }\end{array}$ & $\begin{array}{l}\text { Intervention } \\
\text { subjects }\end{array}$ & $\begin{array}{l}\text { Control } \\
\text { Subjects }\end{array}$ & $\begin{array}{l}\text { Length of } \\
\text { follow up }\end{array}$ & $\begin{array}{c}\text { Type \& } \\
\text { frequency of } \\
\text { BP self } \\
\text { measurement }\end{array}$ & $\begin{array}{l}\text { Description of } \\
\text { the control } \\
\text { group }\end{array}$ & $\begin{array}{l}\text { Intervention group } \\
\text { regimen over and } \\
\text { above control plus } \\
\text { self-monitoring }\end{array}$ & $\begin{array}{l}\text { Adjustment made } \\
\text { for self- } \\
\text { measurement } \\
\text { readings }\end{array}$ & $\begin{array}{l}\text { Was physician } \\
\text { adjusting } \\
\text { medication aware } \\
\text { of self } \\
\text { measurement } \\
\text { readings? }\end{array}$ \\
\hline $\begin{array}{l}\text { Carnahan } \\
1975 \\
\text { US }^{26}\end{array}$ & $\begin{array}{l}\text { Hospital clinic, } \\
\text { patients starting } \\
\text { treatment for } \\
\text { hypertension, } \\
\text { with } D B P \geq 90\end{array}$ & 55 & 49 & 48 & $\begin{array}{l}2-8 \text { clinic } \\
\text { visits per } \\
6 \text { months }\end{array}$ & $\begin{array}{l}\text { Manual sphyg } \\
\text { with built in } \\
\text { stethoscope } \\
\text { Twice daily } \\
\text { (upper arm) }\end{array}$ & $\begin{array}{l}\text { Medication } \\
\text { adjustment by } \\
\text { fixed titration } \\
\text { schedule } \\
\text { based on clinic } \\
\text { BP values } \\
\text { done by nurse }\end{array}$ & $\begin{array}{l}\text { No additional co- } \\
\text { intervention }\end{array}$ & None specified & $\begin{array}{l}\text { No: } \\
\text { Nurse run clinic } \\
\text { blind to home BP }\end{array}$ \\
\hline $\begin{array}{l}\text { Haynes } \\
1976 \\
\text { US }^{16}\end{array}$ & $\begin{array}{l}\text { Non compliant } \\
\text { men recruited via } \\
\text { workplace } \\
\text { screening } \\
\text { programme; DBP } \\
\geq \quad 90 \mathrm{mmHg} \\
\text { following initial } \\
\text { treatment }\end{array}$ & $\begin{array}{l}\text { No age } \\
\text { quoted }\end{array}$ & 20 & 18 & $\begin{array}{c}0 \& 6 \\
\text { months }\end{array}$ & $\begin{array}{l}\text { Manual } \\
\text { anaeroid } \\
\text { Daily } \\
\text { (upper arm) }\end{array}$ & Not specified & $\begin{array}{l}\text { Patient education } \\
\text { and tailored to their } \\
\text { rituals }\end{array}$ & None specified & Not clear \\
\hline $\begin{array}{l}\text { Johnson a * } \\
1978 \\
\text { Canada }^{15}\end{array}$ & $\begin{array}{l}\text { Subjects } \\
\text { recruited from } \\
\text { screening in local } \\
\text { shopping centre, } \\
\text { DBP } \geq 95 \mathrm{mmHg} \\
\text { despite treatment }\end{array}$ & 54 & 36 & 36 & $\begin{array}{l}0,2 \mathrm{wks} \\
\& 6 \\
\text { months }\end{array}$ & $\begin{array}{l}\text { Manual sphyg } \\
\text { Daily } \\
\text { (upper arm) }\end{array}$ & $\begin{array}{l}\text { Neither home } \\
\text { visits or self- } \\
\text { recording }\end{array}$ & $\begin{array}{l}\text { No additional co- } \\
\text { intervention }\end{array}$ & None specified & Yes \\
\hline $\begin{array}{l}\text { Johnson b* } \\
1978 \\
\text { Canada }^{15}\end{array}$ & $\begin{array}{l}\text { Subjects } \\
\text { recruited from } \\
\text { screening in local } \\
\text { shopping centre, } \\
\text { DBP } \geq 95 \mathrm{mmHg} \\
\text { despite treatment }\end{array}$ & 54 & 35 & 36 & $\begin{array}{l}0,2 \mathrm{wks} \\
\& 6 \\
\text { months }\end{array}$ & $\begin{array}{l}\text { Manual sphyg } \\
\text { Daily } \\
\text { (upper arm) }\end{array}$ & $\begin{array}{l}\text { Neither home } \\
\text { visits or self- } \\
\text { recording }\end{array}$ & $\begin{array}{l}\text { Home visits every } 4 \\
\text { weeks }\end{array}$ & None specified & Yes \\
\hline
\end{tabular}




\begin{tabular}{|c|c|c|c|c|c|c|c|c|c|c|}
\hline Study & $\begin{array}{l}\text { Setting and } \\
\text { subjects }\end{array}$ & $\begin{array}{l}\text { Mean } \\
\text { Age } \\
\text { (years) }\end{array}$ & $\begin{array}{l}\text { Intervention } \\
\text { subjects }\end{array}$ & $\begin{array}{l}\text { Control } \\
\text { Subjects }\end{array}$ & $\begin{array}{l}\text { Length of } \\
\text { follow up }\end{array}$ & $\begin{array}{lr}\begin{array}{lr}\text { Type } & \& \\
\text { frequency } & \text { of } \\
\text { BP } & \text { self } \\
\text { measurement }\end{array}\end{array}$ & $\begin{array}{l}\text { Description of } \\
\text { the control } \\
\text { group }\end{array}$ & $\begin{array}{l}\text { Intervention group } \\
\text { regimen over and } \\
\text { above control plus } \\
\text { self-monitoring }\end{array}$ & $\begin{array}{l}\text { Adjustment made } \\
\text { for } \\
\text { measurement } \\
\text { readings }\end{array}$ & $\begin{array}{l}\text { Was physician } \\
\text { adjusting } \\
\text { medication aware } \\
\text { of } \\
\text { measurement } \\
\text { readings? }\end{array}$ \\
\hline $\begin{array}{l}\text { Earp } \\
1982 \\
\text { US }^{27}\end{array}$ & \begin{tabular}{lr}
\multicolumn{2}{c}{ Treated } \\
hypertensives \\
with a medication \\
change $r$ in \\
previous 2 & mths \\
recruited & from \\
hospital & and \\
community & \\
clinics &
\end{tabular} & 48 & 99 & 63 & $\begin{array}{c}24 \\
\text { months; } \\
5-6 \text { visits }\end{array}$ & $\begin{array}{l}\text { Sphygmomano } \\
\text { meter type } \\
\text { unclear }\end{array}$ & $\begin{array}{l}\text { Routine } \\
\text { medical care }\end{array}$ & $\begin{array}{l}\text { Home visit and } \\
\text { significant others } \\
\text { involved }\end{array}$ & None specified & Not clear \\
\hline $\begin{array}{l}\text { Stahl } \\
1984 \\
\text { US }^{28}\end{array}$ & $\begin{array}{l}\text { Hospital clinic. } \\
\text { Raised DBP } \\
\text { under care of } \\
\text { nurse practitioner }\end{array}$ & 47.5 & 144 & 173 & $\begin{array}{c}36 \\
\text { months, } \\
\text { variable } \\
\text { number of } \\
\text { visits }\end{array}$ & Mercury Sphyg & Not specified & $\begin{array}{l}\text { No additional co- } \\
\text { intervention }\end{array}$ & None specified & yes \\
\hline $\begin{array}{l}\text { Binstock } \\
1988 \\
\text { US }^{17}\end{array}$ & $\begin{array}{l}\text { Treated } \\
\text { hypertensives }\end{array}$ & $\begin{array}{l}\text { Not } \\
\text { stated }\end{array}$ & 23 & 32 & $\begin{array}{l}0 \& 12 \\
\text { months }\end{array}$ & $\begin{array}{l}\text { Not stated. } \\
\text { Readings done } \\
\text { at home }\end{array}$ & $\begin{array}{l}\text { Education } \\
\text { programme }\end{array}$ & $\begin{array}{l}\text { educational } \\
\text { programme plus } \\
\text { self-monitoring }\end{array}$ & None specified & Not stated \\
\hline $\begin{array}{l}\text { Midanik } \\
1991 \\
\text { US }^{29}\end{array}$ & $\begin{array}{l}\text { Untreated with } \\
\mathrm{BL} \quad \mathrm{DBP} \text { 90- } \\
95 \mathrm{mmHg} \text { and } \\
\mathrm{SBP}<180 \mathrm{mmHg}\end{array}$ & 47 & 102 & 102 & $\begin{array}{c}0 \& 12 \\
\text { months }\end{array}$ & $\begin{array}{l}\text { Digital device. } \\
2 \text { consecutive } \\
\text { readings, twice } \\
\text { a week }\end{array}$ & Usual care & $\begin{array}{l}\text { No additional co- } \\
\text { intervention }\end{array}$ & None specified & Yes \\
\hline $\begin{array}{l}\text { Soghikhan } \\
1992 \\
\text { US }^{12}\end{array}$ & $\begin{array}{l}\text { Health } \\
\text { Maintenance } \\
\text { Organisation } \\
\text { Centres. } \\
\text { Hypertension } \\
\text { patients }\end{array}$ & 54 & 215 & 215 & $\begin{array}{l}0 \& 12 \\
\text { months }\end{array}$ & $\begin{array}{l}\text { Electronic } \\
\text { sphyg } \\
\text { Twice weekly }\end{array}$ & Usual care & $\begin{array}{l}\text { No additional co- } \\
\text { intervention }\end{array}$ & None specified & Yes \\
\hline
\end{tabular}




\begin{tabular}{|c|c|c|c|c|c|c|c|c|c|c|}
\hline Study & $\begin{array}{l}\text { Setting and } \\
\text { subjects }\end{array}$ & $\begin{array}{l}\text { Mean } \\
\text { Age } \\
\text { (years) }\end{array}$ & $\begin{array}{l}\text { Intervention } \\
\text { subjects }\end{array}$ & $\begin{array}{l}\text { Control } \\
\text { Subjects }\end{array}$ & $\begin{array}{l}\text { Length of } \\
\text { follow up }\end{array}$ & $\begin{array}{lr}\text { Type } & \& \\
\text { frequency of } \\
\text { BP self } \\
\text { measurement }\end{array}$ & $\begin{array}{l}\text { Description of } \\
\text { the control } \\
\text { group }\end{array}$ & $\begin{array}{l}\text { Intervention group } \\
\text { regimen over and } \\
\text { above control plus } \\
\text { self-monitoring }\end{array}$ & $\begin{array}{l}\text { Adjustment made } \\
\text { for } \\
\text { measurement } \\
\text { readings }\end{array}$ & $\begin{array}{l}\text { Was physician } \\
\text { adjusting } \\
\text { medication aware } \\
\text { of } \\
\text { measurement self } \\
\text { readings? }\end{array}$ \\
\hline $\begin{array}{l}\text { Muhlhauser \# } \\
1993 \\
\text { Germany } \\
{ }^{30}\end{array}$ & $\begin{array}{l}\text { Primary } \text { Care. } \\
\text { BP> } 160 \text { and/or } \\
95 \mathrm{mmHg}\end{array}$ & 51 & 86 & 74 & $\begin{array}{l}0 \& 18 \\
\text { months }\end{array}$ & $\begin{array}{l}\text { Twice daily } \\
\text { until } \\
\text { satisfactory } \\
\text { values } \\
\text { achieved then } \\
\text { less frequently }\end{array}$ & Normal care & Patient education & None specified & Yes \\
\hline $\begin{array}{l}\text { Friedman } \\
1996 \\
\text { US }^{31}\end{array}$ & $\begin{array}{l}\text { Community } \\
\text { physicians' } \\
\text { clinics. Treated } \\
\text { hypertensives } \\
\text { with SBP } \geq \\
160 \mathrm{mmHg} \text { and/or } \\
\text { DBP } \geq \\
90 \mathrm{mmHg}\end{array}$ & 77 & 133 & 134 & $\begin{array}{c}0 \& 6 \\
\text { months }\end{array}$ & $\begin{array}{l}\text { Automated } \\
\text { Weekly } \\
\text { (?upper arm) }\end{array}$ & Usual care & $\begin{array}{l}\text { Patient education } \\
\text { and telemetry }\end{array}$ & None specified & $\begin{array}{lr}\text { "TLC" } & \text { data } \\
\text { transmitted } & \text { to } \\
\text { patient's } & \text { own } \\
\text { physician } & \end{array}$ \\
\hline $\begin{array}{l}\text { Bailey } \\
1999 \\
\text { Australia } 32\end{array}$ & $\begin{array}{l}\text { Primary care. } \\
\text { Hypertensive } \\
\text { patients not } \\
\text { practising self- } \\
\text { measurement, } \\
\text { with or without } \\
\text { current treatment }\end{array}$ & 55 & 31 & 29 & $\begin{array}{l}0 \& 8 \\
\text { weeks }\end{array}$ & $\begin{array}{l}\text { Electronic } \\
\text { Twice daily } \\
\text { (upper arm) }\end{array}$ & $\begin{array}{l}\text { ACE inhibitor } \\
\text { or diuretic }\end{array}$ & $\begin{array}{l}\text { No additional co- } \\
\text { intervention }\end{array}$ & None specified & Yes \\
\hline $\begin{array}{l}\text { Vetter } \\
2000 \\
\text { Switzerland }{ }^{33}\end{array}$ & $\begin{array}{l}\text { Primary care. } \\
\text { Newly } \\
\text { diagnosied or } \\
\text { known } \\
\text { hypertensives } \\
\text { with BP } 160 / 200 / \\
95-215 \mathrm{mmHg}\end{array}$ & 58 & 296 & 326 & $\begin{array}{l}0,2 \& 8 \\
\text { weeks }\end{array}$ & $\begin{array}{l}\text { Automated } \\
\text { (wrist) } \\
\text { Twice daily }\end{array}$ & Losartan $15 \mathrm{mg}$ & $\begin{array}{l}\text { No additional co- } \\
\text { intervention }\end{array}$ & None specified & $\begin{array}{l}\text { Not applicable } \\
\text { (patients were only } \\
\text { reviewed at the } \\
\text { beginning and end } \\
\text { of the } 8 \text { week study } \\
\text { period) }\end{array}$ \\
\hline
\end{tabular}




\begin{tabular}{|c|c|c|c|c|c|c|c|c|c|c|}
\hline Study & $\begin{array}{l}\text { Setting and } \\
\text { subjects }\end{array}$ & $\begin{array}{l}\text { Mean } \\
\text { Age } \\
\text { (years) }\end{array}$ & $\begin{array}{l}\text { Intervention } \\
\text { subjects }\end{array}$ & $\begin{array}{l}\text { Control } \\
\text { Subjects }\end{array}$ & $\begin{array}{l}\text { Length of } \\
\text { follow up }\end{array}$ & 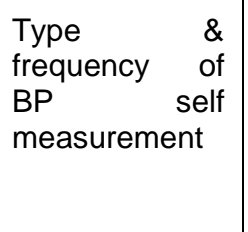 & $\begin{array}{l}\text { Description of } \\
\text { the control } \\
\text { group }\end{array}$ & $\begin{array}{l}\text { Intervention group } \\
\text { regimen over and } \\
\text { above control plus } \\
\text { self-monitoring }\end{array}$ & $\begin{array}{l}\text { Adjustment made } \\
\text { for } \\
\text { measurement } \\
\text { readings }\end{array}$ & $\begin{array}{l}\text { Was physician } \\
\text { adjusting } \\
\text { medication aware } \\
\text { of } \\
\text { measurement self } \\
\text { readings? }\end{array}$ \\
\hline $\begin{array}{l}\text { Mehos } \\
2000 \\
\text { US }^{34}\end{array}$ & $\begin{array}{l}\text { Primary care } \\
\text { patients with } \\
\text { treated } \\
\text { hypertension and } \\
\text { BP between } 140- \\
179 / 90- \\
109 \mathrm{mmHg}\end{array}$ & 59 & 18 & 18 & $\begin{array}{l}0 \& 6 \\
\text { months }\end{array}$ & $\begin{array}{l}\text { Manual } \\
\text { electronic } \\
\text { Daily } \\
\text { Upper arm }\end{array}$ & $\begin{array}{lr}\text { Routine } & \text { care } \\
\text { with } & \text { no } \\
\text { restrictions } & \text { on } \\
\text { number } & \text { of } \\
\text { office visits. }\end{array}$ & $\begin{array}{l}\text { Phone call from } \\
\text { pharmacist }\end{array}$ & None specified & Yes \\
\hline $\begin{array}{l}\text { Artinian } \\
2001 \\
\text { US }^{35}\end{array}$ & $\begin{array}{l}\text { Family } \\
\text { Community } \\
\text { Centre. African- } \\
\text { American men } \\
\text { and women with } \\
\mathrm{BP} \geq \\
140 \text { and/or } 90 \\
\text { (diabetic range } \geq \\
130 / 85 \text { ) }\end{array}$ & 59 & 6 & 9 & $\begin{array}{l}0 \& 3 \\
\text { months }\end{array}$ & $\begin{array}{l}\text { Electronic, at } \\
\text { home, } \\
\text { minimum } \\
\text { times/week }\end{array}$ & $\begin{array}{lr}\begin{array}{l}\text { Usual } \\
\text { visits }\end{array} & \text { care; } \\
\text { primary } & \text { to } \\
\text { provider } & \text { care } \\
\text { intervals } & \text { at } \\
\text { requested by } \\
\text { the primary } \\
\text { care provider. }\end{array}$ & $\begin{array}{lr}\text { Telemetry, } & \text { patient } \\
\text { education } & \text { and } \\
\text { nurse visit } & \end{array}$ & None specified & Yes \\
\hline $\begin{array}{l}\text { Broege } \\
2001 \\
\text { US }^{22}\end{array}$ & $\begin{array}{l}\text { Hypertension } \\
\text { centre or } \\
\text { community ory } \\
\text { health centre. } \\
\text { Hypertensive } \\
\text { patients with } \mathrm{BP}< \\
150 / 90 \text { if on } \\
\text { treatment } \\
>150 / 90 \text { or } \\
\text { treatment }\end{array}$ & 73 & 20 & 20 & $\begin{array}{l}0,1,2 \& \\
3 \text { months }\end{array}$ & $\begin{array}{l}\text { Semi- } \\
\text { automatic, } 3 \\
\text { times morning } \\
\text { and evening }\end{array}$ & $\begin{array}{l}\text { Usual clinic } \\
\text { treatment }\end{array}$ & $\begin{array}{l}\text { Monthly clinic visit } \\
\text { and nurse phone } \\
\text { call }\end{array}$ & No adjustment & Yes \\
\hline
\end{tabular}




\begin{tabular}{|c|c|c|c|c|c|c|c|c|c|c|}
\hline Study & $\begin{array}{l}\text { Setting and } \\
\text { subjects }\end{array}$ & $\begin{array}{l}\text { Mean } \\
\text { Age } \\
\text { (years) }\end{array}$ & $\begin{array}{l}\text { Intervention } \\
\text { subjects }\end{array}$ & $\begin{array}{l}\text { Control } \\
\text { Subjects }\end{array}$ & $\begin{array}{l}\text { Length of } \\
\text { follow up }\end{array}$ & $\begin{array}{lr}\text { Type } & \& \\
\text { frequency } & \text { of } \\
\text { BP } & \text { self } \\
\text { measurement }\end{array}$ & $\begin{array}{l}\text { Description of } \\
\text { the control } \\
\text { group }\end{array}$ & $\begin{array}{l}\text { Intervention group } \\
\text { regimen over and } \\
\text { above control plus } \\
\text { self-monitoring }\end{array}$ & $\begin{array}{l}\text { Adjustment made } \\
\text { for } \\
\text { measurement } \\
\text { readings }\end{array}$ & $\begin{array}{l}\text { Was physician } \\
\text { adjusting } \\
\text { medication aware } \\
\text { of } \\
\text { measurement self } \\
\text { readings? }\end{array}$ \\
\hline $\begin{array}{l}\text { Rudd } \\
2004 \\
\text { US }^{36}\end{array}$ & $\begin{array}{l}\text { Primary Care } \\
\text { clinics. } \\
\text { Hypertensive } \\
\text { patients with BP } \\
\geq \\
140 / 90 \text { or on } \\
\text { anti- } \\
\text { hypertensives, } \\
\text { eligible for } \\
\text { treatment under } \\
\text { JNC VI criteria }\end{array}$ & 59.5 & 74 & 76 & $\begin{array}{l}0,3, \& 6 \\
\text { months }\end{array}$ & $\begin{array}{l}\text { Automated, } \\
\text { twice daily, at } \\
\text { home }\end{array}$ & $\begin{array}{l}\text { Routine care } \\
\text { as received } \\
\text { before study }\end{array}$ & $\begin{array}{l}\text { Patient education } \\
\text { and nurse phone } \\
\text { call }\end{array}$ & $\begin{array}{l}\text { Adjustment of } \\
10 / 5 \mathrm{mmHg}\end{array}$ & Yes \\
\hline $\begin{array}{l}\text { Baque \# } \\
2005 \\
\text { Spain } \\
{ }^{37}\end{array}$ & $\begin{array}{l}\text { Primary Care } \\
\text { centres. } \\
\text { Hypertensive } \\
\text { patients with BP } \\
\geq \\
140 / 90 \mathrm{mmHg}\end{array}$ & 61 & 622 & 703 & $\begin{array}{c}0,6,8 \\
14,16 \& \\
24 \text { wks }\end{array}$ & 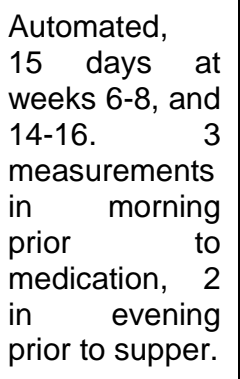 & None specified & $\begin{array}{l}\text { No additional co- } \\
\text { intervention }\end{array}$ & None specified & $\begin{array}{lr}\begin{array}{lr}\text { Encouraged } \\
\text { share }\end{array} & \text { to } \\
\text { physician. } & \text { with } \\
\end{array}$ \\
\hline $\begin{array}{l}\text { Halme } \\
2005 \\
\text { Finland } \\
38\end{array}$ & $\begin{array}{l}\text { Primary Health } \\
\text { Care. Patients } \\
\text { with essential } \\
\text { hypertension, } \\
\text { taking anyti- } \\
\text { hypertensive } \\
\text { treatment or BP } \\
\geq \\
140 / 90\end{array}$ & 57 & 113 & 119 & $\begin{array}{l}0 \& 6 \\
\text { months }\end{array}$ & $\begin{array}{ll}\text { Automatic } & \\
\text { home } & \\
\text { readings. } & 1 \\
\text { week every } & 2 \\
\text { months, twice } \\
\text { daily }\end{array}$ & $\begin{array}{l}\text { Usual care; at } \\
\text { regular local } \\
\text { practice }\end{array}$ & $\begin{array}{l}\text { No additional co- } \\
\text { intervention }\end{array}$ & $\begin{array}{l}\text { Adjustment } \\
5 / 5 \mathrm{mmHg}\end{array}$ & Yes \\
\hline
\end{tabular}




\begin{tabular}{|c|c|c|c|c|c|c|c|c|c|c|}
\hline Study & $\begin{array}{l}\text { Setting and } \\
\text { subjects }\end{array}$ & $\begin{array}{l}\text { Mean } \\
\text { Age } \\
\text { (years) }\end{array}$ & $\begin{array}{l}\text { Intervention } \\
\text { subjects }\end{array}$ & $\begin{array}{l}\text { Control } \\
\text { Subjects }\end{array}$ & $\begin{array}{l}\text { Length } \\
\text { of follow } \\
\text { up }\end{array}$ & 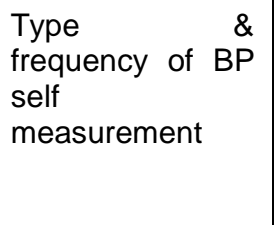 & $\begin{array}{l}\text { Description of } \\
\text { the control } \\
\text { group }\end{array}$ & $\begin{array}{l}\text { Intervention group } \\
\text { regimen over and } \\
\text { above control plus } \\
\text { self-monitoring }\end{array}$ & $\begin{array}{l}\text { Adjustment made } \\
\text { for } \\
\text { measurement } \\
\text { readings }\end{array}$ & $\begin{array}{l}\text { Was physician } \\
\text { adjusting } \\
\text { medication aware } \\
\text { of } \\
\text { measurement } \\
\text { readings? }\end{array}$ \\
\hline $\begin{array}{l}\text { McManus } \\
2005 \\
\text { UK }^{6}\end{array}$ & $\begin{array}{l}\text { Primary Care. } \\
\text { Treated } \\
\text { hypertensives } \\
\text { with BP 140- } \\
200 / 85- \\
100 \mathrm{mmHg}\end{array}$ & 62 & 214 & 227 & $\begin{array}{l}0,6, \quad \& \\
12 \\
\text { months }\end{array}$ & $\begin{array}{l}\text { Electronic Upper } \\
\text { Arm monthly in } \\
\text { practice waiting } \\
\text { room }\end{array}$ & Usual care & $\begin{array}{l}\text { No additional co- } \\
\text { intervention }\end{array}$ & No adjustment & $\begin{array}{l}\text { Patients } \\
\text { encouraged to } \\
\text { share readings } \\
\text { (approx } 50 \% \text { did) }\end{array}$ \\
\hline $\begin{array}{l}\text { Zillich \# } \\
2005 \\
\text { US }^{39}\end{array}$ & $\begin{array}{l}\text { Community } \\
\text { pharmacies. } \\
\text { Treated } \\
\text { hypertensives } \\
\text { with BP 145- } \\
179 / 95-109 \\
\text { (diabetic } \\
135-179 / 90- \\
109 \mathrm{mmHg})\end{array}$ & 65 & 64 & 61 & $\begin{array}{l}0,4, \quad \& \\
12 \text { wks }\end{array}$ & $\begin{array}{l}\text { Automatic. } 2 \\
\text { readings } \\
\text { separated with } 5 \\
\text { min rest, once } \\
\text { daily in the } \\
\text { morning }\end{array}$ & $\begin{array}{l}3 \text { pharmacy } \\
\text { visits over } \\
3 \text { mths where } \\
\text { BP measured } \\
\text { nad referred to } \\
\text { physician if } \\
>140 / 90 \mathrm{mmHg}\end{array}$ & $\begin{array}{l}\text { Patient education. } \\
\text { Additional visit to } \\
\text { implement } \\
\text { treatment } \\
\text { developed based } \\
\text { on self readings. }\end{array}$ & No adjustment & Yes \\
\hline $\begin{array}{l}\text { Marquez- } \\
\text { Contreras } \\
2006 \\
\text { Spain }\end{array}$ & $\begin{array}{l}\text { Primary care } \\
\text { centres. Mild- } \\
\text { moderate } \\
\text { hypertension, } \\
\text { requiring } \\
\text { treatment (not } \\
\text { all on } \\
\text { treatment at } \\
\mathrm{BL} \text { ) }\end{array}$ & 59 & 100 & 100 & 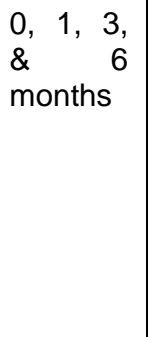 & $\begin{array}{lr}\text { Automatic. } & 3 \\
\text { days a } & \text { week, } \\
\text { twice } & \text { before } \\
\text { breakfast } & \text { and } \\
\text { twice } & \text { before } \\
\text { supper } & \end{array}$ & $\begin{array}{l}\text { Usual } \\
\text { treatment from } \\
\text { GP }\end{array}$ & $\begin{array}{l}\text { No additional co- } \\
\text { intervention }\end{array}$ & None specified & $\begin{array}{l}\text { No, readings given } \\
\text { to investigator who } \\
\text { altered } \\
\text { medications. }\end{array}$ \\
\hline $\begin{array}{l}\text { Verberk } \\
2007 \\
\text { Netherlands }{ }^{13}\end{array}$ & $\begin{array}{l}\text { Setting, } \begin{array}{r}\text { not } \\
\text { clear. }\end{array} \\
\text { BP }>139 \\
\text { and } / \text { or } \\
89 \mathrm{mmHg}\end{array}$ & 55 & 214 & 216 & $\begin{array}{l}0 \text { \& } 12 \\
\text { months }\end{array}$ & $\begin{array}{l}\text { Automated. } 6 \\
\text { times a day for } 7 \\
\text { days }\end{array}$ & $\begin{array}{l}\text { Step-wise anti- } \\
\text { hypertensive } \\
\text { treatment } \\
\text { based on office } \\
\text { readings. }\end{array}$ & $\begin{array}{l}\text { No additional co- } \\
\text { intervention }\end{array}$ & No adjustment & Yes \\
\hline
\end{tabular}




\begin{tabular}{|c|c|c|c|c|c|c|c|c|c|c|}
\hline Study & $\begin{array}{l}\text { Setting and } \\
\text { subjects }\end{array}$ & $\begin{array}{l}\text { Mean } \\
\text { Age } \\
\text { (years) }\end{array}$ & $\begin{array}{l}\text { Intervention } \\
\text { subjects }\end{array}$ & $\begin{array}{l}\text { Control } \\
\text { Subjects }\end{array}$ & $\begin{array}{l}\text { Length } \\
\text { of follow } \\
\text { up }\end{array}$ & $\begin{array}{l}\text { Type } \& \\
\text { frequency of BP } \\
\text { self } \\
\text { measurement }\end{array}$ & $\begin{array}{l}\text { Description of } \\
\text { the control } \\
\text { group }\end{array}$ & $\begin{array}{l}\text { Intervention group } \\
\text { regimen over and } \\
\text { above control plus } \\
\text { self-monitoring }\end{array}$ & $\begin{array}{l}\text { Adjustment made } \\
\text { for } \\
\text { measurement } \\
\text { readings }\end{array}$ & $\begin{array}{l}\text { Was physician } \\
\text { adjusting } \\
\text { medication aware } \\
\text { of } \\
\text { measurement } \\
\text { readings? }\end{array}$ \\
\hline $\begin{array}{l}\text { Green }^{*} \text { a } \\
2008 \\
\text { USA }^{14}\end{array}$ & $\begin{array}{l}\text { Medical } \\
\text { Centres. } \\
\text { Uncontrolled } \\
\text { treatment } \\
\text { hypertension }\end{array}$ & 59 & 259 & 258 & $\begin{array}{l}0 \& 12 \\
\text { months }\end{array}$ & $\begin{array}{l}\text { Automated. At } \\
\text { least two days } \\
\text { per week, twice } \\
\text { per occasion }\end{array}$ & Usual care & $\begin{array}{l}\text { Received } \\
\text { hypertension } \\
\text { pamphlet and } \\
\text { patient web-site } \\
\text { pamphlet Use of } \\
\text { website plus patient } \\
\text { education }\end{array}$ & $\begin{array}{l}\text { Adjustment } \\
5 / 5 \mathrm{mmHg}\end{array}$ & Yes \\
\hline $\begin{array}{l}\text { Green * b } \\
2008 \\
\text { USA }^{14}\end{array}$ & $\begin{array}{l}\text { Medical } \\
\text { centres. } \\
\text { Uncontrolled } \\
\text { treatment } \\
\text { hypertension }\end{array}$ & 59 & 261 & 258 & $\begin{array}{l}0 \& 12 \\
\text { months }\end{array}$ & $\begin{array}{l}\text { Automated. At } \\
\text { least two days } \\
\text { per week, twice } \\
\text { per occasion }\end{array}$ & Usual care & $\begin{array}{l}\text { Received } \\
\text { hypertension } \\
\text { pamphlet and } \\
\text { patient web-site } \\
\text { pamphlet Use of } \\
\text { website and } \\
\text { pharmacist plus } \\
\text { patient education }\end{array}$ & $\begin{array}{l}\text { Adjustment } \\
5 / 5 \mathrm{mmHg}\end{array}$ & Yes \\
\hline $\begin{array}{l}\text { Madsen } \\
2008 \\
\text { Denmark }^{23}\end{array}$ & $\begin{array}{l}\text { General } \\
\text { practices. } \\
\text { Newlty } \\
\text { diagnosed or } \\
\text { treated but not } \\
\text { controlled, } \\
\text { office BP } \\
>150 / 95 \mathrm{mmHg}\end{array}$ & 56 & 113 & 123 & $\begin{array}{l}0 \& 6 \\
\text { months }\end{array}$ & $\begin{array}{l}\text { Semi-automatic. } \\
3 \times / w k \text { in } 1^{\text {st }} 3 \\
\text { months, then } \\
\text { once a wk during } \\
\text { last } 3 \text { months. } 3 \\
\text { readings each } \\
\text { time. }\end{array}$ & Usual care & telemonitoring & $\begin{array}{l}\text { Adjustment } \\
5 / 5 \mathrm{mmHg}\end{array}$ & yes \\
\hline $\begin{array}{l}\text { Parati } \\
2009 \\
\text { Italy }{ }^{18}\end{array}$ & $\begin{array}{l}\text { Uncontrolled } \\
\text { essential } \\
\text { hypertension, } \\
\text { BP } \geq 140 / 90, \\
\text { plus ABPMR } \\
130 / 80 \text { with or } \\
\text { without } \\
\text { treatment }\end{array}$ & 57.5 & 187 & 111 & 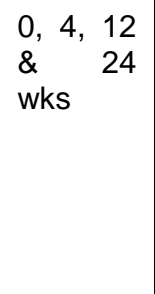 & Variable & $\begin{array}{l}\text { Office based } \\
\text { BP } \\
\text { management }\end{array}$ & $\begin{array}{l}\text { Nurse phone call } \\
\text { and telemetry }\end{array}$ & $\begin{array}{l}\text { Adjustment } \\
5 / 5 \mathrm{mmHg}\end{array}$ & yes \\
\hline
\end{tabular}


Table 2: Results from the main meta-regression analyses.

\begin{tabular}{|c|c|c|c|c|}
\hline \multicolumn{5}{|c|}{ Systolic Office Meta-regression } \\
\hline & \multicolumn{3}{|c|}{ Overall backward elimination model } & \multirow{2}{*}{$\begin{array}{l}\text { Single moderator } \\
\text { model } \\
\mathrm{p} \\
\end{array}$} \\
\hline Moderator & Coeff & $\mathrm{p}$ & $95 \% \mathrm{CI}$ & \\
\hline Follow-up & -0.17 & 0.57 & -0.77 to .44 & 0.42 \\
\hline Age & 0.39 & 0.31 & -0.40 to 1.18 & 0.80 \\
\hline Male & 0.09 & 0.43 & -0.14 to .31 & 0.66 \\
\hline$\overline{\mathrm{DBP}}$ & 0.50 & 0.88 & -6.55 to 7.56 & 0.93 \\
\hline $\begin{array}{l}\text { Co- } \\
\text { Interventions }\end{array}$ & -4.10 & 0.25 & -11.47 to 3.26 & 0.28 \\
\hline Adjusted BP & -2.16 & 0.56 & -9.89 to 5.56 & 0.48 \\
\hline constant & -24.65 & 0.28 & -72.06 to 22.75 & \\
\hline \multicolumn{5}{|c|}{ Diastolic Office Meta-regression } \\
\hline & \multicolumn{3}{|c|}{ Overall backward elimination model } & $\begin{array}{l}\text { Single moderator } \\
\text { model }\end{array}$ \\
\hline Moderator & Coeff & $\mathrm{p}$ & $95 \% \mathrm{CI}$ & $\mathrm{p}$ \\
\hline Follow-up & 0.04 & 0.68 & -0.16 to 0.24 & 0.55 \\
\hline Age & 0.02 & 0.90 & -0.26 to 0.30 & 0.22 \\
\hline Male & 0.04 & 0.31 & -0.04 to 0.12 & 0.22 \\
\hline DBP & -0.41 & 0.75 & -3.04 to 2.24 & 0.59 \\
\hline $\begin{array}{l}\text { Co- } \\
\text { Interventions }\end{array}$ & -1.67 & 0.24 & -4.52 to 1.19 & 0.13 \\
\hline Adjusted BP & -0.96 & 0.52 & -3.99 to 2.10 & 0.83 \\
\hline constant & -2.57 & 0.77 & -20.06 to 15.09 & \\
\hline \multicolumn{5}{|c|}{ Target Office Meta-regression } \\
\hline & \multicolumn{3}{|c|}{ Overall backward elimination model } & $\begin{array}{l}\text { Single moderator } \\
\text { model }\end{array}$ \\
\hline Moderator & Coeff & $\mathrm{p}$ & $95 \%$ CI & $\mathrm{p}$ \\
\hline Follow-up & -0.0002 & 0.99 & -0.06 to 0.06 & 0.65 \\
\hline Age & 0.008 & 0.83 & -0.08 to 0.10 & 0.43 \\
\hline Male & -0.005 & 0.72 & -0.04 to 0.03 & 0.60 \\
\hline DBP & -0.087 & 0.81 & -0.94 to 0.76 & 0.92 \\
\hline $\begin{array}{l}\text { Co- } \\
\text { Interventions }\end{array}$ & 0.41 & 0.14 & -0.17 to 0.99 & 0.04 \\
\hline Adjusted BP & 0.19 & 0.54 & -0.52 to 0.90 & 0.33 \\
\hline constant & -0.60 & 0.84 & -7.31 to 6.12 & \\
\hline
\end{tabular}




\section{Reference List}

1. Mathers, C. D., Bernard, C., Iburg, C. M., Innoue, M., Fat, D. M., Shibuya, K., Stein, C., Tomijima, N., and $\mathrm{Xu}, \mathrm{H}$. Global Burden of Disease in 2002: data sources, methods and results. 54. 2003. Geneva, WHO.

2. Montgomery AA, Fahey T, Ben Shlomo Y, Harding J. The influence of absolute cardiovascular risk, patient utilities, and costs on the decision to treat hypertension: a Markov decision analysis. J Hypertens. 2003;21:1753-1759.

3. Psaty BM, Lumley T, Furberg CD, Schellenbaum G, Pahor M, Alderman MH, Weiss NS. Health outcomes associated with various antihypertensive therapies used as first-line agents: a network metaanalysis. JAMA 2003;289:2534-2544.

4. Wolf-Maier K, Cooper RS, Kramer H, Banegas JR, Giampaoli S, Joffres MR, Poulter N, Primatesta P, Stegmayr B, Thamm M. Hypertension Treatment and Control in Five European Countries, Canada, and the United States. Hypertension 2004;43:10-17.

5. Cappuccio FP, Kerry SM, Forbes L, Donald A. Blood pressure control by home monitoring: meta-analysis of randomised trials. BMJ 2004;329:145-151.

6. McManus RJ, Mant J, Roalfe A, Oakes RA, Bryan S, Pattison HM, Hobbs FDR. Targets and self monitoring in hypertension: Randomised controlled trial and cost effectiveness analysis. BMJ 2005;331:493496.

7. Bobrie G, Chatellier G, Genes N, Clerson P, Vaur L, Vaisse B, Menard J, Mallion JM. Cardiovascular Prognosis of "Masked Hypertension" Detected by Blood Pressure Self-measurement in Elderly Treated Hypertensive Patients. JAMA 2004;291:1342-1349.

8. Little P, Barnett J, Barnsley L, Marjoram J, Fitzgerald-Barron A, Mant D. Comparison of agreement between different measures of blood pressure in primary care and daytime ambulatory blood pressure. BMJ 2002;325:254

9. Steel N. Thresholds for taking antihypertensive drugs in different professional and lay groups: questionnaire survey. BMJ 2000;320:1446-1447.

10. Fahey T, Schroeder K, Ebrahim S. Interventions used to improve control of blood pressure in patients with hypertension. Cochrane.Database.Syst.Rev. 2005;CD005182

11. Juni $\mathrm{P}$, Witschi A, Bloch R, Egger M. The hazards of scoring the quality of clinical trials for meta-analysis. JAMA 1999;282:1054-1060.

12. Soghikian K, Casper SM, Fireman BH, Hunkeler EM, Hurley LB, Tekawa IS, Vogt TM. Home blood pressure monitoring. Effect on use of medical services and medical care costs. Med.Care 1992;30:855-865.

13. Verberk WJ, Kroon AA, Lenders JW, et al. Self-measurement of blood pressure at home reduces the need for antihypertensive drugs: a randomized, controlled trial. Hypertension 2007;50:1019-1025.

14. Green BB, Cook AJ, Ralston JD, Fishman PA, Catz SL, Carlson J, Carrell D, Tyll L, Larson EB, Thompson RS. Effectiveness of home blood pressure monitoring, Web communication, and pharmacist care on hypertension control: a randomized controlled trial. JAMA 2008;299:2857-2867.

15. Johnson AL, Taylor DW, Sackett DL, Dunnett CW, Shimizu AG. Self-recording of blood pressure in the management of hypertension. Can.Med Assoc.J 1978;119:1034-1039.

16. Haynes RB, Sackett DL, Gibson ES, Taylor DW, Hackett BC, Roberts RS, Johnson AL. Improvement of medication compliance in uncontrolled hypertension. Lancet 1976;1:1265-1268. 
17. Binstock ML, Franklin KL. A comparison of compliance techniques on the control of high blood pressure. Am.J Hypertens. 1988;1:192S-194S.

18. Parati G, Omboni S, Albini F, Piantoni L, Giuliano A, Revera M, Illyes M, Mancia G. Home blood pressure telemonitoring improves hypertension control in general practice. The TeleBPCare study. $\mathrm{J}$ Hypertens. 2009;27:198-203.

19. Marquez-Contreras E, Martell-Claros N, Gil-Guillen V, De La Figuera-Von Wichmann, Casado-Martinez JJ, Martin-De Pablos JL, Figueras M, Galera J, Serra A. Efficacy of a home blood pressure monitoring programme on therapeutic compliance in hypertension: The EAPACUM-HTA study. Journal of Hypertension. 2006;24:169-175.

20. Oxman AD, Thomson MA, Davis DA, Haynes RB. No magic bullets: a systematic review of 102 trials of interventions to improve professional practice. CMAJ 1995;153:1423-1431.

21. Brueren MM, Petri $\mathrm{H}$, van Weel $\mathrm{C}$, van Ree JW. How many measurements are necessary in diagnosing mild to moderate hypertension? Fam.Pract. 1997;14:130-135.

22. Broege PA, James GD, Pickering TG. Management of hypertension in the elderly using home blood pressures. Blood Press Monit. 2001;6:139-144.

23. Madsen LB, Kirkegaard P, Pedersen EB. Blood pressure control during telemonitoring of home blood pressure. A randomized controlled trial during 6 months. Blood Press 2008;17:78-86.

24. Pickering TG, Miller NH, Ogedegbe G, Krakoff LR, Artinian NT, Goff D. Call to action on use and reimbursement for home blood pressure monitoring: a joint scientific statement from the American Heart Association, American Society Of Hypertension, and Preventive Cardiovascular Nurses Association. Hypertension 2008;52:10-29.

25. Staessen JA, Den HE, Celis H, Fagard R, Keary L, Vandenhoven G, O'Brien ET. Antihypertensive treatment based on blood pressure measurement at home or in the physician's office: a randomized controlled trial. JAMA 2004;291(8):955-964.

26. Carnahan JE, Nugent CA. The effects of self-monitoring by patients on the control of hypertension. Am.J Med Sci. 1975;269:69-73.

27. Earp JA, Ory MG, Strogatz DS. The effects of family involvement and practitioner home visits on the control of hypertension. Am.J.Public Health 1982;72:1146-1154.

28. Stahl SM, Kelley CR, Neill PJ, Grim CE, Mamlin J. Effects of home blood pressure measurement on longterm BP control. Am.J.Public Health 1984;74:704-709.

29. Midanik LT, Resnick B, Hurley LB, Smith EJ, McCarthy M. Home blood pressure monitoring for mild hypertensives. Public Health Rep. 1991;106:85-89.

30. Mulhauser I, Sawicki PT, Didjurheit U, Jorgens V, Trampisch HJ, Berger M. Evaluation of a structured treatment and teaching programme on hypertension in general practice. Clin.and Exper.Hypertension 1993;15:125-142.

31. Friedman RH, Kazis LE, Jette A, Smith MB, Stollerman J, Torgerson J, Carey K. A telecommunications system for monitoring and counseling patients with hypertension. Impact on medication adherence and blood pressure control. Am.J Hypertens. 1996;9:285-292.

32. Bailey B, Carney SL, Gillies AA, Smith AJ. Antihypertensive drug treatment: a comparison of usual care with self blood pressure measurement. J Hum.Hypertens. 1999;13:147-150.

33. Vetter W, Hess L, Brignoli R. Influence of self-measurement of blood pressure on the responder rate in hypertensive patients treated with losartan: results of the SVATCH Study. Standard vs Automatic Treatment Control of COSAAR in Hypertension. J.Hum.Hypertens. 2000;14:235-241. 
34. Mehos BM, Saseen JJ, MacLaughlin EJ. Effect of pharmacist intervention and initiation of home blood pressure monitoring in patients with uncontrolled hypertension. Pharmacotherapy 2000;20:13841389.

35. Artinian NT, Washington OG, Templin TN. Effects of home telemonitoring and community-based monitoring on blood pressure control in urban African Americans: a pilot study. Heart Lung 2001;30:191-199.

36. Rudd P, Miller NH, Kaufman J, Kraemer HC, Bandura A, Greenwald G, Debusk RF. Nurse management for hypertension. A systems approach. Am.J.Hypertens. 2004;17:921-927.

37. Baque A, Capillas PR, Guarch RM, Figueras SM, Ylla-Catala PA, Balana VM, Vidal TJ, Cobos CA. [Effectiveness of self-measurement of blood pressure in patients with hypertension: the Dioampa study]. Aten.Primaria 2005;35:233-237.

38. Halme L, Vesalainen R, Kaaja M, Kantola I. Self-monitoring of blood pressure promotes achievement of blood pressure target in primary health care. Am.J Hypertens. 2005;18:1415-1420.

39. Zillich AJ, Sutherland JM, Kumbera PA, Carter BL. Hypertension outcomes through blood pressure monitoring and evaluation by pharmacists (HOME study). J.Gen.Intern.Med. 2005;20:1091-1096. 